nchmenden Professor der ökonomischen Wissenschaft hintreten, um sich prüfen zu lassen : er würde durchfallen"

Weit is, dat iedere levering op rekening ran het herstel, die naar Frankrijk ging, bijna antomatisch werd en wordt begroet met het luidruchtig verzet ran den daarbij betrokken tak der indusirie. De eerste vrucht, die Engeland van den boom der overwinning plukte, was de benadeeling zijner industrie door de Duitsche inflatieprijzen. Erger nog voor dat land is de expansie van Amerika en de industrialiseering van landen, die vroger slechts grondstoffen leverden. De sociale erisis, dic in nauw verband met den afzeterisis opkwam, heeft haar hoogtepunt nog lang niet bereikt.

Len ander gevolg van den oorlog is het prestigeverlies der staten. De aanvangen daarvan liggen reeds in de toestanden vóór den oorlog, toen er ook reeds strijd tussehen het besef der rolkscenheid en de huishoudelijke (wirtschaftliche) belangen der groepen bestond. Sedert den oorlog vallen de volken meer (n meer in groepen uiteen, waarin het privaathuishoudelijk belang de overhand heeft: ,Ws handelt sich um eine Sprengung der stanten durch dic Wirtschaft". Onderwijl de regeeringen onder elkander over een zekerheidspact onderhandelen, confeleeren terloops de industrieën en sluiten zich meer en meer tot groote luropeesche ssudicaten aaneen. Daar deze noodzakelijk zijn voor het vortbestann van gene behoort hun de toekomst. 'T'egenover deze belangen zijn alle zekerheidspacten papier. Telwijl de politieke eliques der onderscheiden naties met elkander strijden, breidt de ,huishoudelijke" cenheid zich ongemerkt uit.

1) oorlogsschadevergoeding is een fiasco gebleken. Ook het I)awesplan. Het is ontworpen vanuit het standpunt van den bankier, die slechts getallen ziet, doch niet genoeg rekening houdt met de .,productiontechnische" gevolgen der betalingen vool de betrokken landen.

()erschrijving tot betaling ran schulden kan Duitschland slechts doen als zijn handelsbalans actief is en dat kan slechts worden bereikt door concurveerende leveringen op groote schaal aan liet buitenland. De nuren der beschermende rechten, die allerwege worden opgericht, zijn daaraan niet bevorderlijk. Dawesplan en beschermende handelspolitiek zijn onverzoenbare tegenstellingen.

„Die schutzzollwelle, die heute durch die Wolt geht. mutet an wic ein Rückwärtstasten nach dem Althergebrachten, wie cine krampfhafte Terteidigung einer Position, nur um sich für den Augenblick zu sichern, während sich doch die weltwirtschaftliche Gesammtlage gr'undlegend verändert hat. Ws ist als habe man noch nicht den Mut zu der gänzlich neuen ökonomischen Begriffswclt, dic nötig ist, um die ungeahnten internationalen Währungsprobleme zu bemeistern, die am Horizont cmporsteigen. Anch in Amerika gibt es heute schon kritische Stimmen, die darauf hinweisen, dass das Land seine Schutzzollmauern abbauen müsse, da es nicht bis in die Hwigkeit, weitergehen hïnne, dass es sich den Ueberschuss seiner Handelsbilanz in Gold bezahlen lasse".

In zijn slotwoord vraagt de schrịver warvoor men in I) uitschland in politiek opzicht eigenlijk vreest. De reusachtige !nilitaire maatregelen, die Frankrijk neemt zijn reeds thans niet meer evenredig aan zijn rolkshuishoudelijke kracht. De finanricele toestand van Frankrijk is troosteloos. De wereldhuishouding laat niet met zich spotten. Tret militaire apparaat zal het land meer en meer ten val worden. De finantieele basis der Furopeesche staten, die bij een eventuecle nieuwen oorlog hetrokken zouden zijn, is maar Amerika verlegd; de kansen, dat de ,Schlacht der Zukunft" ooit zal worden gevoerd, zijn uiterst grering.
Ook in Engreland nemen de binnenlandsche moeilijkheden toe. boor de bolchewistische besmetting der vakverecnigingen is een hres geslagen in de vastheid van het Staatsgebouw en de vloed van rolkshuishoudelijke nooden verlamt de regeering meer en meer. Men vechte in Duitschland niet tegen schaduwen. De ware ploblemen zịn van volkshuishoudelijken aard; zij zouden grootendeels blijven bestaan, ook als de onmogelijke politicke velhoudingen geregeld waren. Wat vóór alles noodig is : oog voor de werkelijkheid ,Tatsachensin"........ „Der Geist der Sachlichkeit........" muss wieder zu Worte kommen........ Fs hat keinen 7weck, das Weltgeschehen auf das Koordinatensystem des eigenen Privatgeschmackes $\mathrm{zu}$ beziehen und danach entweder gutzuheissen oder zu verdammen......... Alle Kritik, die einen bestehenden Zusammenhang verurteilt - nur weil el dem ureigensten Privatinteresse des Kritikers zu widerläuft - ist unfruchtbar. 'Die Mehrzahl aller Kritiken, die an wirtschaftlichen Verhältnissen geübt. werden, ist so geartet."

De noodlottige ontwikkeling der dingen kan slechts worden gestuit, wanneer het inzicht, dat dit tot iederen prijs en onmiddellijk geschieden moet algemeen werd en de houding van leider's en massa ging bepalen. Met, dat de schrijver dit zogt, spreekt hịj er echter zijn twijfel over uit, of inzicht den loop van het volkshuishoudelijke leven wel werkelijk kan beinvloeden. Do verschillende sociale groepen laten zich daardoor nauwelijks leiden. Zoolang de mogelijkheid hestaat, op de onde wijs velder te leven, zal men het doen. De arbeider zal eischen blijven stellen, de ondernemer verder huishouden in den ouden stijl, zonder zich om de fundamenteele veranderingen der wereldhuishouding te bekommeren, het geldkapitaal zal in den strijd om eigen machtspositie "Orgien feieren".

Dool den socialen haat worden heden nog geweldige krachten mutteloos verspild. Het heeft geen zin meer, clkander wederkeerig in. slaap te wiegen omtrent de volkshuishoudelijke voolnitzichten.

Het zorgeloos voortleven als in een roes zal voor een bezonnen levenswijze moeten wijken. Nuchterheid is thans in Duitschland meer noodig dan pathos. Slechts zóó zal men de moeilijkheden kunnen te boven komen. warvoor het thans levend geslacht rich door een hard noodlot ziet gesteld.

Ian beherlscht sein Schiksal, indem man es erfüllt".

C. VERWEY

\section{UIT EN VOOR DE PRAKTIJK} Red.: ABR. MEY en JAMES POLAK

\section{UITWERKING OPGAVE No. 32}

(Onderzoek in strafzaak wegens verduistering).

Amsterdam, 24 .Januari 1927

Den Edelachtbaren Ieer Rechter Commissaris belast met de hehandeling van Strafzaken bij de Arrondissementsrechtbank te Amsterdam den Heer Mr. A. C. de Graaf te Amsterdam.

\section{i.z. Openb. Min. contra P. Smits.}

Edelachtbare Heer,

Ingevolge uwe opdracht van 2 Dee. 1926 No...... zijn door ondergetcekende onderzocht de stukken, hem daarbij overge. $\log d$.

Id vrang 1.

Was er op 24 Sept. 1926 een tekort in verdachlote's kas en hoo groot? 
Verdachte P. Smits was hlịkens mededeeling van zijn patroon J. Gerritsen als kassier belast met het bijhouden der kas-, bank- en debiteurenadministratie.

Op 25 sept. j.l. werd hịj bịj afwezigheid wegens ziekte vervangen door den hulpboekhouder $H$. Jansen, aan wien de sleutels der kas op dien dag zịn afgegeven door' den heer Gerritsen dadelijk nadat deze ze op zijn kantoor van een huisgenoot van verdachte had in ontvangst genomen.

Door .Jansen is verzuimd de kas bij overname op te maken. Dit geschiedde pas op Zaterdag 30 Sept. d.a.v. Volgens zijn procesverbaal van kasopmaking (No. 13 van het dossier) bedroeg het tekort in kas toen $f$.......... Deze kasopmaking is door den heer Gerritsen geverifieerd.

Daarop is door den hoofdboekhouder A. Willems een voorloopig onderzock der boeken geschied, hetgeen tot de ontdekking van diverse onregelmatigheden leidde. Deze zijn nader gespecificeerd in de stukken No. ....

Op 4 Ince. j.l. is door ondergeteekende een kasopneming geschied (dossier Nr. A), waarbij de kas bleek te sluiten, in aanmerking nemend, dat op 31 Oet. j.l. een uitgaafpost is geboekt van $f$......... warvoor onder Debiteuren de rekening $P$. Smits is belast.

Ondergeteekende heeft het kasboek in ontvangst en uitgaaf rreteld over het tijdvak 25/9-2/12'26 en de posten vergeleken met de bewijsstukken. Fen en ander is in orde bevonden.

Op grond hiervan is ondergeteekende overtuigd van de juist. heid van het procesverbaal d.d. 30/9/'26 (doss. No. 13).

Of het daarbij geconstateerde tekort ad $f$........ ook reeds bestond op 24/9/'26 kan niet nader worden vastgesteld, aangezien bij overname der kas door hulphoekhouder .J. geen kas is opgemaakt.

Vervolgens heeft ondergeteekende de stukken, opgemaakt door hoofdbockhouder $W$., met de boeken vergeleken en komt tot de slotsom, dat het bovenbedoelde kastekort nog moet worden verhoogd met $f$.......... als volgt:

a. Tan dehitenren ontvangen tegen per order geteekende kwitantie maar niet geboekt in het kasboek, noch in het dehiteurenbock, zie lijst 1,8 posten ad $f$.........

b. als voren, niet geboekt in het kasboek, maar wel in het debiteurenhoek, zie lijst 2,6 posten ad $f$........

c. geboekt als betaald voor ingekochte emballage, mar van de inkoopfactuur afgetrokken vlg. bịg. kwitanties, zie lịst 3 . 12 posten ad $f$..........

d. geboekt als terugbetaald voor retour-emballage, maar gedekt door vervalschte bons blijkens orig. souches in het bonboek van den magazịnmeester, 19 posten, versehil vlg. lijst 4 $f$...........

c. kasbock-uitgaafposten, niet overeenkomend met de betr. bewijsstukken. 5 posten, versehil lijst $5 f \ldots \ldots, \ldots$

Het tekort per 24/9/'26 wordt mitsdien in totaal becijferd op $f \ldots \ldots \ldots \ldots$.

Het onderzoek is geschied vanaf 1 Nov. 1925, den datum. warop verdachte tot kassier is bevorderd.

Blijkens een proces-verbaal van kasopneming is toen de kas sluitend aan hom overgedragen.

\section{Ad vraag 2.}

Hoe kan het tekort zijn ontstaan?

Het valt buiten de beoordeeling van ondergeteckende, of verdachte's leefwijze aanleiding was tot het onttrekken van gelden aan de kas; vast staat wel. dat de gcheel onvoldoende controle van kas on boeken daartoe de gelegenheid heeft geboden.

1. Kascontrole. In plaats van op ongeregelde tijdstippen ge- schiedde deze op den eersten van elke maand door den patroon zelf. Deze controle was nogal oppervlakkig, aangezien althans de laatste twee maal 1 Aug. on 1 Sept. 1926 ontvangsten eenige dagen later goboekt zijn. ITit de begoleidende brieven van de posten ad $f$.....,... en $f$........ d.d. ..... blijkt zulks. Bij afwerigheid van den patroon werd deze controle wel cens overgeslagen.

Door deze tactick vielen verschillen niet op.

rerdachte heeft in 1926 wegens drukke werkzaamheden geen vacantie genomen. Anders was een verschil allicht iets eer ontdekt.

2. Tele betalingen en ontvangsten loopen over de kas. Het lịkt zeer wel mogelijk de meeste posten over de bankrekening te laten loopen, waardoor de kans op fraude zeer vermindert.

3. Kuitanties. Thet per order teekenen van ongenummerde kwitanties zonder souche makte eenige controle daarop onmogrelijk.

4. Vergelijken beuijsstuliten met booking in kasboek bleef gcheel achterwege.

5. Onvoldoende interne controle der boeken.

a. Slechts 1 maal per jaar werd nagegaan, of debiteuren- en (rediteurenboeken sluiten met het grootboek. Het verschil over 1925 was betrekkelijk gering en is niet uitgezocht. Begin 1926 is cen vrij belangrijk verschil ontdekt, maar door drukte is ook dit blijven loopen. De hoofdbockhouder had hierop bchooren aan te dringen, toen verdachte ermee in gebreke blecf.

b. Tergelịking van inkoopbock en magazijnboek bleef achterwege. Anders was de vervalsching der emballagebons ontd.okt.

De verrichte werkzaamheden blịken alle uit het rapport.

(Geteekend)

MOED EN VERTROUWEN.

\section{BEOORDEELING No. 32.}

IIOED EN TERTROTWEN. Wij plaatsen nwe uitwerking rooral, onılat wij die, wat den vorm betreft, goedkeuren.

$[T$ loopt wel wat gemakkelịk over de vraag heen of het tekort misschien tussehen 24 en 29 September kan zijn ontstaan. Daartoc is cen zeer speciale controle van die paar dagen noodig. Theeft de plaatsvervanger in de drukte van den eersten dag misschien een nitgaaf vergeten te boeken? Het zou dan wel eens kumnen blijken, dat het geheele geval een mug blijkt te ziin. die tot olifant gemaakt is.

Beter lijkt ons wat dienaangaande .Naar Beste Weten" veronderstelt.

Van belang is hierbij natuurlijk de indruk, die de boekhouding van den plaatsvervanger maakt wat betreft accuratesse en betrouwhaarheid. Klopte de kas onmiddellịjk of eerst nadat cen aantal fouten verbeterd waren?

IT zult dan ook aan dic laatste periode meer moeten doen dan controleeren met bewijsstukken, $\mathrm{nml}$. nagaan of de boekingen volledig zijn on wel meer speciaal tusschen 24 en 29 Sept. wat betreft de uitgaven, daarna wat betreft de ontrangsten.

$\mathrm{I}^{\top}$ moet ook niet zeggen, dat het buiten uwe beoordeeling valt of verdarhte's leefwïze aanleiding gaf tot ......... enz. Hiermede hebt $I^{\top}$ reeds iets gezegd - althans dat zal de lezer, in casu de officier van justitie er in leggen - terwijl TT daarmaar gecn zelfstandig onderzoek hebt ingesteld.

Dat de verrichte handelingen zoo hec] precies nit het rapport blijken, kummen we niet eens zijn. 
Wij zijn zoo vrij dit aan te vullen met:

Volledige controle kasbock vanaf 1 Nov. 1925 tot op datum van onderzock met aanwezige externe bescheiden alsmede met alle beschikbare interne aanteckeningen. Daarbij rooral op data letten en bij eventueelen twijfel aanvragen.

Overzicht maken van verloop kassaldi.

Protocollen nagaan van kasopmakingen on te zien of kas toen klopte en hiermede geen fouten gemaakt zijn.

Volledige controle bankboek over zelfde periode op dezelfde wịze en bovendien met RgCt bank.

Dehiteuren RgCt over zelfde periode volledig afrekenen. Vel'loop ran iedere rekening zolgruldig nagaan, teneinde vast te stellen of er annleiding is tot vermoeden dat meer of vroeger betadd werd dan gebockt. Zulks speciaal wat betreft de rekeningen warrop volgens rapport Willenis onregelmatigheden zouden voorkomen; doch niet uitsluitend deze.

Aan die Debiteuren wier rekening twijfel wekken vragen wat en wammeer hetaald en kwitanties ter inzage vragen.

Fene opstelling maken van de voor emballage betaalde en ontvangen bedlagen met in beide gevallen de restituties daasop cn le epenstaande posten nauwkeurig nagaan, aangezien el cen vrij groot risico bestaat, dat te min ontvangen restituties 'n to vecl verlecule restituties geboekt zijn..

\section{6 punten.}

H. L. te R. I' moet ook wat meer aandacht schenken aan de nicuwe periode.

Dat de patroon de copiefacturen moet doorloopen zal geen warborg geven voor de volledigheid. Het is veel verlangd, dat hij moct opletten als er en ontbreekt.

In dit geval zouden we zeker niet met cen totaal controle op de Debiteuren volstaan. Het gaat juist in 't bijzonder om de data.

Van de debiteuren, die beweren betaald te hebben, moet $\mathrm{I}^{\top}$ de kwitantie ter inzage vragen.

Hot is principicel verkeerd overleg to plegen met den patroon omtrent den omvang uwer" controle. Ook de patroon kan belang zien in een onjuist rapport al is het maar alleen uit wrakancht. Als L meent te zeggen, dat U den omvang uwer controle wilt vaststellen in verhand met de van den patroon ontvangen inlichtingen dan is het wat anders.

Een volledige balans behoeft $U$ niet op te stellen. Daar komen tal van posten op voor, die voor dit onderzock zonder belang zijn.

7 punten.

STROOHALM. In 't algemeen goed opgezet, vooral hetgeen IT aan de periode na ontslag doet. In nw rapport konit U tot to positieve conclusies.

U moet niet alleen controleeren met externe bewijsstukken. naar wel degelijk nota nomen van interne gegevens; niet om daaruit positicve conclusies te trekken, maar wel om aanwijzingen te vinden wat nog dieper te onderzoeken is.

\section{7 punten.}

POCHN. T' drukt $T^{\top}$ in $u w$ rapport veel te positicf uit naar annleiding van ontvangen mededeelingen. Zoo ergens dan geldt hier art. 4 van het $R$. v. $A$. volgens 't welk $T^{\top}$ geen nededeelingen van anderen moogt eiteeren zonder de bron te vermelden. Ook wat de patroon T vertelt zon kunnen hlijken onjuist to zijn en mag door uw eitaat nict de waarde van cene deskundige verklaring krịgen.

IIet is niet per se noodig de geheele goederen-en crediteurenadministratic te controlecren. Indien verdachte's bockingen in overeenstenming zijn net de aanteekeningen van personen, (hijk. magazijnmeester) die intern behoorlijk gecontroleerd worden en tegen wie geen verdenking bestaat, is er geen aanleiding te veronderstellen, dat die samen met den kassier geknoeid zou hebben. Dat zou een geheel nieuw geval zijn. Iets anders is het echter als de boekingen in de kas bijv. niet kloppen met de amuteckeningen van den magazijnmeester. Dan moet $\mathrm{U}$ trachten uit te zoeken bij wie van beiden de fout schuilt.

Vin groot belang is dat bij de kascontrole bịzondere maatregelen te nemen zijn om - beter dan dat als regel mogelijk isvast te stellen of alles op den goeden datum goboekt is. Mogelijk blijkt uit het or(lerboek op welken datum een klant uit de provincie op kantoor gewcest is cn waarschịnlijk heeft betaald. $\mathrm{Na}$ rectificatie der clatums is dan vast te stellen hoe het verloop ran het kassaldo is geweest.

6 punten.

STRLVERR. IT zijt niet benoemd door de rechthank, doch door den Rechter Commissaris. Waaruit leidt $T$ af, dat de zaak zoo spoedeischend is? ,Z, "7oo spoedig mogelijk" beteekend natuurlijk ,,zoo spoedig als behoorlijk mogelijk is"," Vindt IT darartoe noodig de volledige administratic over drie jaar te controlecren dan is er geen excuus om het niet to doen. De vraag is echter, waartoe is dat noodig? IT wilt toch niet zeggen, dat het nict noodig zou zijn als ,, cen bekende accountant" de balansen geteekend had. Zelfs bij controle van, niet alleen den meest bekenden. maar den meest bekwamen accountant, kan het noodig zijn later ecn speciaal onderzock betreffende fraude in te stellen.

U wart wel gelukkig zoo ommiddellijk to kunnen vaststellen, dat er geen medeplichtigen waren.

,verschillende nitgaven ..... hleken gefingeerd, terwijl ook de kasbewijzen ontbraken".

UT bedoelt waarschịnlịjk: ,aangezien de kashewijzen ontbreken en evenmin op andere wijze de juistheid dezer bockingen bleck, moet ik aannemen, dat ze gefingeerd zijn'".

TT zoekt de oorzaak wel wat nitsluitend bij den patroon.

4 punten.

NAAR BESTE WETEN. Wij eiteeren de volgende alinea's van uw rapport omdat dit juist aan de geplatatste uitwerking ontbreckt :

De bewering van Van der Tak (den nieuwen kassier, dat het tekort op 24/9 bestond) wint zeer an waarschijnlijkheid door de volgende omstandigheden:

1․ Als er dien norgen reeds een , kastekort" was van $f$.......... was het aanwezige kasgeld van $f$......... ontocreikend voor hetgeen op dien dag zeker zoul te betalen zijn. Bịj de bank was cen luim voldoende saldo aanwezig. Het was noodig, daar ongeveer $f$......... of te nemen als hedoeld tekort reeds hestond. Fen dergelijke dispositie heeft inderdaad plaats gehad: $\mathrm{cr}^{\mathrm{i}}$ is n.l. $f$......... opgrenonen. De ........ bank heeft mịj schriftelijk medegedecld, dat de uithetaling daapvan in elk geval vóór $10 \mathrm{uur}$ moet hehben plaats gehad. Wrar de sleutels der kas ongeveer half 10 aan Van der Tak zijn ter hand gesteld, hecft hị hlịkbaar direct na het zien der aanwezige gelden het noodig geoordecld, over genoemd hedrag to doen disponeeren.

$2 \circ$. Het kasboek geeft reeks vanaf ..... nimmer ocn saldo aan. lager dan $f$......... In dit verband doon do disposities bịj de bank voor eimen kasgeld dikwijls vreemd aan. 7oo beloopen te betalingen op Woenstag, den betaaldag, in den regel ongereer $f$.......... en behoefde er 
ook op Woensday ........... niet op een hooger bedrag te worden gerekend. Ilet kasboek gaf op den vorigen dag een saldo aan van $f$.......... dat is dus zeker meer dan genoeg voor de te verwachten betalingen. Toch deed Smits over $f$.......... disponeeren.

Herhalend, dat ik op het onder a genoemde niet met volstrekte zekerheid antwoorden kan, kon ik tot de conclusie, dat het bestaan van een tekor't in verdachte's kas ad $f \ldots \ldots, \ldots$ op Vijjdag 24 September 1926, zeer wel mogelijk, zooal niet zeer waarschijnlijk, is.

Overigens wordt uw rapport wel wat onduidelijk door breed. sprakigheid en door meer dan noodzakelijk indeelen in hoofd. stukken.

Zoo zal menige lezer veronderstellen, dat het boven gecitcerde de eindeonclusie is en verwonderd zijn als $U$ daarma nog met andere tekorten aan komt.

6 punten.

'T KAN BETER. Natuurlijk moet U hier, zoowel als bij iederc andere controle, el tegen waken, dat de cijfer's tijdens uw werk veianderd worden. Wij zien echter niet in, dat dit punt zoo speciaal op den voorgrond gesteld moet worden, daar U toch wol zult bemerken als iemand met een ander handschrift bij de boeken geweest is.

Wr zijn veel belangrijkere punten, waarop te letten valt. De stijl van uw rapport is op sommige plaatsen wat huiselijk en vaak te positief. Men zou haast zeggen, dat $\mathrm{L}^{\circ}$ er een genoegen in schept zooveel gevonden te hebben. Als er inderdaad een verdachte in voorarrest zat, zoudt $U$ er wel anders over' denken

5 punten.

\section{VRAGENBUS}

Vragen omtrent onderwerpen, die voor den accountant in de uitoefening van zijn beroep van bclang kunnen zijn, kunnen worden ingezonden bij den Secretaris van de Redactie.

De Redactie is bereid, om de grenzen, waarbinnen de vragen, die voor beantwoording in aanmerking komen, zoo ruim mogelijk te stellen, zoodat zoowel die van juridischen, als die van bedrïfshuishoudkundigen aard daar binnen vallen, mits de vragen slechts blijven binnen het gebied, dat het blad dienen wil.

De beantwoording geschiedt door één der medewerkers of redactieleden individueel, zoodat de antwoorden niet mogen worden geacht steeds de meening der Redactie in har geheel weer te geven.

VRAAG No. 12

\section{Waardeering van cliënten}

Komt op een liquidatiebalans betreffende een Maatschap vall 2 accountants een post voor, welke aangeeft de waarde der cliënten, zoo ja, hoe moet voor een dergelijken post de waardeering plaats vinden?

\section{Antwoord}

(of op de liquidatie-balans van een maatschap vall accountants een post voor zal komen, welke de waarde aangeeft der cliënten, hangt geheel af van het contract, dat de maatschap gedurende haar bestaan heeft geregeerd, en van de bepalingen betreffende de liquidatie gemaakt.
Als elk der leden na de liquidatie zijn eigen cliënten blịft helienen, is het mogelijk dat er geen afzonderlijke post is uitgetrokken. Is de liquidatie verool'zaakt door het overlijden ran een der vennooten, dan kan de bepaling bestaan hebben, dat de erfgenamen nog eenige jaren een uitkeering genieten. (ook dan is de bedvelde post niet noodig.

Zijn er echter bepalingen, die een dergelijken post noodig maken, dan gelden voor de waardeering m.i. dezelfde regels en voorschuiften als voor elke andere wardeering van goodwill.

G. H.

\section{UIT HET BUITENLAND}

Red.: J. E. ERDMAN, JAC. H. KRAMER en C. J. MEYER (Bijdragen en mededeelingen zende men aan den Secretaris der Redactie)

\section{THE ACCOUNTANT}

\section{To the articled Clerks}

\section{An Exhortation}

Tick, brothers, tick with eare;

But don't tick everything that you see there.

Scrutinise your vouchers, be careful how you tread;

Don't mark one here and there, and take the rest as read.

Despair not when stupendous sums appear in stern array

Of debitor and creditor. Up, brothers, to the fray!

'The timerous heart and fearful soul ne'er made the A.C.A.

$$
\text { So - }
$$

Tick, brothers, tick with care;

But don't tick everything that you see there.

Vouch, brother's, vouch with care;

But don't vouch everything that you sce there.

The written word is as a read; its basis is illusion.

A Balance Sheet may often be a snare and a delusion.

Falsity and falsity may shock your feelings tender,

lisut put credulity aside; all trusting thoughts surrender.

Ingenuous heart, confiding mind ne'er made.

$$
\begin{gathered}
\text { Sir W.ll.n Pl.nd.r } \\
\text { So-- }
\end{gathered}
$$

Vouch, brother's vouch with care;

But don't vouch everything that you see there.

$$
\text { E. C. M. }
$$

(With a small apology to Mark Twain)

In. No. 2712 van 'The Accountant en in het December-nummer van The Incorporated Accountants Journal zijn opgenomen de redevoeringen, welke zijn gehouden tijdens het diner, dat op 4 November a.p. door The Society of Incorporated Accountants and Auditors was georganiseerd bij gelegenheid van de benoeming van den heer E. van Dien tot eerelid van deze vereeniging.

No. 2714 bevat een uit The Accountant's Magazine van November overgenomen artikel Legislation for the Accounting Profession in the Transvaal.

In No. $2 \approx 15$ komt een artikel voor onder den titel Auditors and Communications with Debtors.

Aangezien elke accountant zijn werk uitroert in opdracht van derden, kan er feitelijk alleen maar contact bestaan tus- 